\title{
Provenance of PINDOS FLYSCH DEPOSITS IN METSOVO AND FOURNA AREAS USING SCANNING ELECTRON MICROSCOPY AND MICROANALYSIS
}

\author{
Ananiadis G. ${ }^{1}$, Vakalas I. ${ }^{1}$, Zelilidis A. ${ }^{1}$ and Tsikouras B. ${ }^{2}$ \\ ${ }^{1}$ Laboratory of Sedimentology, Department of Geology, University of Patras, 26500, Patra, \\ Greece,ivakalas@upatras.gr, gananiad@upatras.gr, a.zelilidis@upatras.gr
}

${ }^{2}$ Section of Earth Materials, Department of Geology, University of Patras, 26500, Patra, Greece, v.tsikouras@upatras.gr

\begin{abstract}
Petrographic observation of sandstones that contain detrital grains and lithic fragments along with microanalytical data from certain minerals suggest that detrital material in Pindos flysch deposits, in Metsovo and Fourna areas, may have been sourced in the Pindos ophiolite and the Pelagonian metamorphic rocks; additionally some material from Fournas has probably been derived from the Koziakas ophiolite outcrop. The Loumnitsa Unit (Pindos ophiolite), has probably supplied the Pindos foreland with material from the erosion of amphibolites while the Dramala Unit was the most probable source of spinels and ultramafic material. Fragments of acid plutonic rocks have been observed, too, owing their origin from the plutonite of Varnounta-Kastoria (Pelagonian Zone). The area of Fourna has been also fed by the Koziakas ophiolites, as evidenced from the composition of chlorites and epidotes.
\end{abstract}

\section{INTRODUCTION}

The early Tertiary renewed crustal compression initiated eastward s'dbduction of the remnant Pindos Ocean Basin, where submarine fans accumulated during Paleogene giving rise to the flysch of Pindos zone. Pelagonian zone and ophiolites from the East were thrusted over Pindos flysch deposits during Tertiary. Metsovo and Fournas areas are situated on the Northern and central part of Pindos zone respectively, and they consist of inner and middle fan deposits that infilled the Pindos basin coming from the North (Fig. 1).

\section{ANALYTICAL METHODS}

Samples were collected from the cross-sections A-A' (road from Votonosi to Metsovo) situated in Metsovo area and cross-section B-B' (road from Fournas to Loutra) in NE Karpenisi area. The sandstone samples hao an average thickness of

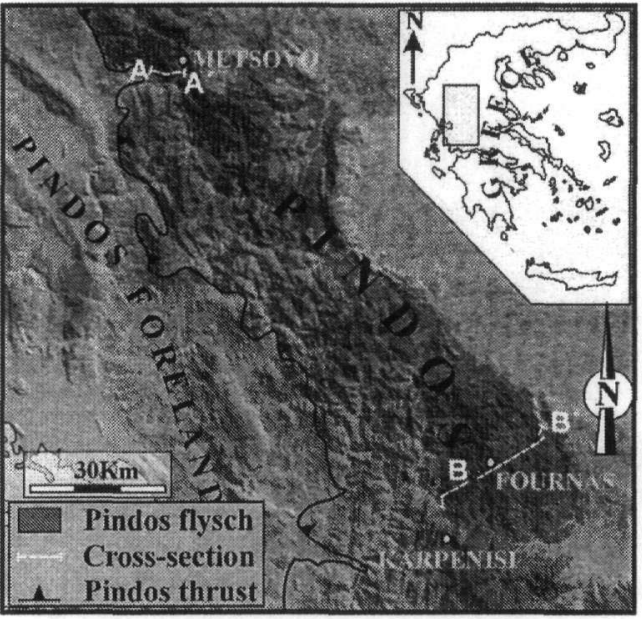

Figure 1. Simplified geological map showing the studied cross-sections. $15 \mathrm{~cm}$ and characterized by the presence of the subdivision Ta of Bouma sequence. Polished thin sections were prepared for petrographic investigation and microanalytical work on certain minerals. Spot microanalyses were performed in polished-thin sections, using a Jeol JSM-6300 SEM equipped with EDS and WDS, with accelerating 
voltage of $20 \mathrm{kV}$ and a beam current of $3 \mathrm{nA}$, in the Laboratory of Electron Microscopy and Microanalysis, University of Patras.

\section{PETROGRAPHY}

The collected sandstone samples from both the Metsovo and Fourna areas contain mainly quartz, alkali feldspars, plagioclase and minor muscovite. Detrital grains are often in both areas. Samples from Metsovo contain less than 15\% lithic fragments while those from Fournas are relatively richer in lithic fragments (up to about 50\%). The observed detrital grains include spinel, titanite, clinopyroxene, garnet, apatite, zircon, plagioclase, K-feldspar (including microcline), epidote, chlorite and rarely tourmaline; in the Fournas area amphibole grains (both magnesiohornblende and tremolite) occur, too. The lithic fragments comprise serpentinites, basaltic rocks (usually displaying typical oceanic alteration), polycrystalline quartz, cherts, granitic rocks (sometimes with perthitic crystals and/o. granophyric textures), dolomites and low-grade metapelitic rocks. The grains are cemented usually with micritic calcite while local sparite occurs, too.

\section{MINERAL CHEMISTRY}

\subsection{Feldspars}

Represenative plagioclase and alkali feldspar analyses are 'sted in Table 1. The analysed plagioclases from Metsovo are mostly albites except one crystal that is andesine (Fig. 2a). Plagioclase grains from Fourna area have variable compositions. The majority of the analysed crystals are albites while a second group clusters at oligoclase and andesine fields (Fig. 2b). Andesines typically occur in intermediate and basic ig' eous rocks while the occurrence of albites is not conclusive since this mineral is hosted in a wide variety of rocks. Distinctly one analysed

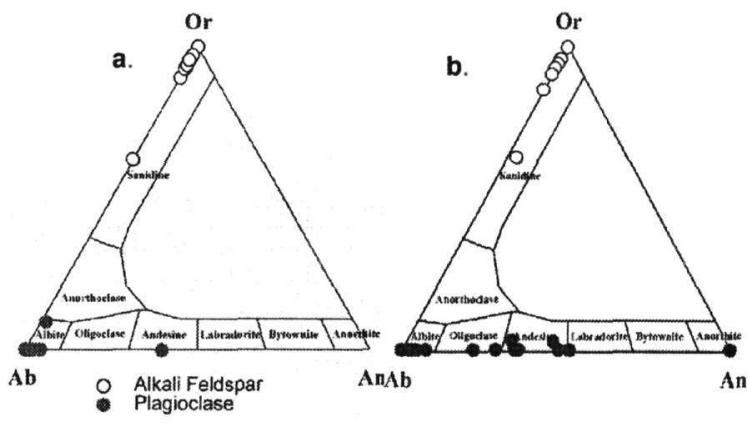

Figure 2. Plot of analysed the detrital feldspars from Metsovon (a) and Fournas (b) on the Or-Ab-An diagram crystal from Fournas is anorthite (Fig.

$2 b$ ). Such plagioclases can be fractionated only by a hydrous magma of primitive arc-tholeiitic composition (e.g. Wilson, 1989) and are commonly present in gabbroic and ultramafic rocks that are related to SSZ regime such as the Pindos ophiolite.

Alkali feldspars from both areas are similar being mostly $\mathrm{K}$-feldspars with $\mathrm{K}_{2} \mathrm{O}$ contents ranging from 15.94 to $16.87 \%$, and compositions from Or $_{95}$ to Org8. One crystal from each area differs in containing significant $\mathrm{Ab}$ content and plots in the area of high-temperature alkali feldspars thus advocating for an origin from acid-intermediate volcanic rocks (Figs. 2a, b).

\subsection{Chlorites}

Representative chlorite analyses from Metsovo and Fournas sandstones are listed in Table 2. According to the classification of Hey (1954) the analysed crystals from Metsovo fall into two distinct groups, thus suggesting probably two different rock sources. The first group includes chlorites of ripidolite to pycnochlorite composition, while the second includes diavantites (Fig. 3a). The chlorites from Fournas sugg sst a different source clustering at the fields of pycnochlorites to diabantine, while one crystal plots as brunsvigite (Fig. 3b). The analysed chlorite crystals from Fournas are comparable to chlorites from mafic rocks of the Koziakas ophiolite (Fig. 3b). 
Table 1. Representative feldspar microanalyses from Metsovo (Mets) and Fournas (F) areas (-: below detection limit)

\begin{tabular}{|c|c|c|c|c|c|c|c|c|c|c|}
\hline & Mets6 & Mets6 & Mets6 & $\mathrm{F} 1$ & F12 & F16 & Mets1 & Mets10 & F1 & F12 \\
\hline & k5(E) & k5(E1) & $\mathrm{K} 2(\mathrm{H})$ & K5(6ß) & K2(9) & K7(3) & $\mathrm{K} 1(4)$ & K1(16) & K4(11) & K1(12) \\
\hline $\mathrm{SiO}_{2}$ & 69.09 & 68.00 & 57.61 & 68.96 & 69.11 & 58.09 & 65.82 & 53.10 & 65.76 & 64.39 \\
\hline $\mathrm{TiO}_{2}$ & - & - & - & - & - & - & - & 0.69 & - & - \\
\hline $\mathrm{Al}_{2} \mathrm{O}_{3}$ & 19.57 & 19.33 & 25.96 & 20.28 & 19.87 & 26.86 & 18.34 & 31.09 & 18.42 & 20.93 \\
\hline $\mathrm{Fe}_{2} \mathrm{O}_{3} \mathrm{t}$ & - & - & - & - & - & - & - & - & - & - \\
\hline $\mathrm{MgO}$ & - & - & - & - & - & - & - & 1.96 & - & - \\
\hline $\mathrm{MnO}$ & - & - & - & - & - & - & - & - & - & - \\
\hline $\mathrm{CaO}$ & - & 0.32 & 8.61 & 0.84 & 0.71 & 9.24 & - & - & - & - \\
\hline $\mathrm{Na}_{2} \mathrm{O}$ & 11.02 & 9.66 & 7.06 & 9.92 & 10.17 & 4.90 & 4.43 & 0.57 & 0.44 & 0.80 \\
\hline $\mathrm{K}_{2} \mathrm{O}$ & - & 1.46 & - & - & - & - & 11.38 & 11.26 & 16.55 & 14.46 \\
\hline $\mathrm{P}_{2} \mathrm{O}_{5}$ & - & - & - & & & - & - & 0.76 & - & - \\
\hline Total & 99.68 & 98.77 & 99.24 & 100.00 & 99.86 & 99.09 & 99.97 & 99.43 & 101.17 & 100.58 \\
\hline \multicolumn{11}{|c|}{ Structural formulae on the basis of 80} \\
\hline $\mathrm{Si}$ & 3.013 & $3.0 \cap 9$ & 2.601 & 2.993 & 3.005 & 2.606 & 2.998 & 2.467 & 3.005 & 2.930 \\
\hline \multirow[t]{2}{*}{$\mathrm{Al}^{\mathrm{N}}$} & - & - & 0.399 & 0.037 & - & 0.419 & 0.002 & 0.533 & - & 0.122 \\
\hline & 3.013 & 3.009 & 3.000 & 3.000 & 3.005 & 3.000 & 3.000 & 3.000 & 3.005 & 3.000 \\
\hline$A l^{n}$ & 1.005 & 1.007 & 0.981 & 1.030 & 1.041 & 1.025 & 0.982 & 1.137 & 0.991 & 1.052 \\
\hline $\mathrm{Ti}$ & - & - & - & - & - & - & - & - & - & - \\
\hline $\mathrm{Cr}$ & - & - & - & & & & - & - & - & - \\
\hline Fet & - & - & - & - & - & - & - & 0.119 & - & - \\
\hline $\mathrm{Mg}$ & - & - & - & $=$ & - & - & - & - & - & - \\
\hline $\mathrm{Mn}$ & - & - & - & - & - & - & - & 0.030 & - & - \\
\hline $\mathrm{P}$ & - & - & - & $\cdot$ & & & - & - & 0.039 & 0.071 \\
\hline $\mathrm{Ca}$ & - & 0.015 & 0.416 & 0.039 & 0.033 & 0.444 & 0.391 & 0.044 & 0.965 & 0.840 \\
\hline $\mathrm{Na}$ & 0.932 & 0.829 & 0.618 & 0.835 & 0.857 & 0.426 & 0.661 & 0.627 & - & - \\
\hline \multirow[t]{2}{*}{$\mathrm{K}$} & - & 0.082 & - & - & - & - & 2.034 & 1.957 & 1.995 & 1.963 \\
\hline & 1.937 & 1.933 & 2.015 & 1.904 & 1.931 & 1.895 & 37.17 & 6.56 & 3.884 & 7.794 \\
\hline$A b$ & $\begin{array}{r}100.0 \\
0 \\
\end{array}$ & 89.52 & 59.40 & 95.538 & 96.292 & $\begin{array}{r}48.96 \\
6 \\
\end{array}$ & - & - & - & - \\
\hline$A n$ & - & 1.62 & 40.60 & 4.462 & 3.708 & $\begin{array}{r}51.03 \\
4 \\
\end{array}$ & 62.83 & 93.44 & 96.116 & 92.206 \\
\hline Or & 0.00 & 8.86 & - & - & - & - & - & - & - & - \\
\hline
\end{tabular}

\subsection{Muscovites}

Representative detrital muscovite grain analyses from Metsovo and Fournas areas are given in Table 3. The Si/Al ${ }^{\mathrm{V}}$ ratio of the studied muscovites is greater than 3 , and Si lies between 3.2 and 3.6 (atoms p.f.u., on the basis of 11 oxygens) indicating increased phengitic component (Massone and Shreyer, 1986). Consequently, their original formation is related to relatively high pressure conditions (Guidotti \& Sassi, 1976, Massone \& Schreyer, 1986). Analogous muscovite crystals are widespread in metapelit 2 rocks from the Pelagonian Zone.

\subsection{Garnets}

Representative garnet analyses are listed in Table 4. The garnet grains from both Metsovo and Fournas areas have two distinct compositions: a grossular-rich and an almandine-rich, revealing two different supply sources. Grossular garnets are commonly found in both ultramafic and metamorphic (amphibolite sole) rocks in ophiolites, while almandine-rich garnets are usually related to metasedimentary rocks of greenschist, amphibolite or/and eclogitic metamorphic facies similar to those occurring in the $\mathrm{P}$.lagonian Zone. 
Table 3 (right). Representative detrital muscovite microanalyses from Metsovo (Mets) and Fourna ( $F)$ areas. (-: below detection limit)

Table 2. Representative chlorite microanalyses from Metsovo (Mets) and Fourna (F) areas. (-: below detection limit)

\begin{tabular}{|c|c|c|c|c|c|}
\hline & Mets1 & Mets 10 & Mets9 & F1 & F12 \\
\hline & $\mathrm{K} 2(6)$ & $\mathrm{K} 3(4)$ & K1(4) & K6(8) & $\mathrm{K} 2(6)$ \\
\hline $\mathrm{SiO}_{2}$ & 25.28 & 26.02 & 25.71 & 35.52 & 25.57 \\
\hline $\mathrm{TiO}_{2}$ & - & - & - & - & - \\
\hline $\mathrm{Al}_{2} \mathrm{O}_{3}$ & 20.77 & 21.11 & 22.91 & 15.22 & 17.99 \\
\hline $\mathrm{Cr}_{2} \mathrm{O}_{3}$ & - & - & - & - & - \\
\hline $\mathrm{FeOt}$ & 24.43 & 26.06 & 27.11 & 19.14 & 34.28 \\
\hline $\mathrm{MgO}$ & 13.03 & 12.50 & 9.72 & 15.32 & 6.02 \\
\hline $\mathrm{MnO}$ & - & 0.43 & 0.46 & - & 1.03 \\
\hline $\mathrm{CaO}$ & 1.24 & - & 0.21 & 0.40 & 0.38 \\
\hline $\mathrm{Na}_{2} \mathrm{O}$ & 1.31 & - & 0.23 & - & 0.43 \\
\hline $\mathrm{K}_{2} \mathrm{O}$ & - & - & - & - & - \\
\hline Total & 86.06 & 85.12 & 86.35 & 85.60 & 85.70 \\
\hline \multicolumn{6}{|c|}{ Structural formulae on the basis of 280} \\
\hline $\mathrm{Si}$ & 5.456 & 5.597 & 5.540 & 7.248 & 5.855 \\
\hline \multirow[t]{2}{*}{$\mathrm{Al}^{\mathrm{IV}}$} & 2.544 & 2.403 & 2.460 & 0.752 & 2.145 \\
\hline & 8.000 & 8.000 & 8.000 & 8.000 & 8.000 \\
\hline $\mathrm{Al}^{\mathrm{VI}}$ & 2.735 & 2.945 & 3.354 & 2.905 & 2.706 \\
\hline $\mathrm{Ti}$ & - & - & - & - & - \\
\hline $\mathrm{Cr}$ & - & - & - & - & - \\
\hline $\mathrm{Fe}^{\mathrm{t}}$ & 4.409 & 4.688 & 4.886 & 3.266 & 6.564 \\
\hline $\mathrm{Mg}$ & 4.192 & 4.009 & 3.123 & 4.660 & 2.055 \\
\hline $\mathrm{Mn}$ & - & 0.078 & 0.084 & - & 0.200 \\
\hline $\mathrm{Ca}$ & 0.287 & - & 0.048 & 0.087 & 0.093 \\
\hline $\mathrm{Na}$ & 0.548 & - & 0.096 & - & 0.191 \\
\hline \multirow[t]{2}{*}{$\mathrm{K}$} & - & - & - & - & - \\
\hline & 12.171 & 11.720 & 11.591 & 10.918 & 11.809 \\
\hline
\end{tabular}

\begin{tabular}{|c|c|c|c|c|}
\hline & Mets 10 & Mets 10 & F1 & F12 \\
\hline & $K 1(5)$ & $k 5(8)$ & $K 2(10)$ & $k 2(15)$ \\
\hline $\mathrm{SiO}_{2}$ & 50.85 & 50.08 & 52.08 & 48.54 \\
\hline $\mathrm{TiO}_{2}$ & - & - & 0.67 & 0.43 \\
\hline $\mathrm{Al}_{2} \mathrm{O}_{3}$ & 25.00 & 29.51 & 29.89 & 37.22 \\
\hline $\mathrm{Cr}_{2} \mathrm{O}_{3}$ & - & - & - & - \\
\hline $\mathrm{FeOt}$ & 6.70 & 4.70 & 3.64 & 0.86 \\
\hline $\mathrm{MgO}$ & 2.34 & 2.14 & 2.00 & - \\
\hline $\mathrm{MnO}$ & - & - & - & - \\
\hline $\mathrm{CaO}$ & 0.63 & - & - & - \\
\hline $\mathrm{Na}_{2} \mathrm{O}$ & 0.56 & 1.17 & - & 1.41 \\
\hline $\mathrm{K}_{2} \mathrm{O}$ & 11.15 & 10.59 & 10.02 & 9.46 \\
\hline Total & 97.23 & 98.19 & 98.30 & 97.92 \\
\hline \multicolumn{5}{|c|}{ Structural formulae on the basis of 220} \\
\hline $\mathrm{Si}$ & 6.829 & 6.584 & 6.722 & 6.221 \\
\hline \multirow[t]{2}{*}{$\mathrm{Al}^{\mathrm{IV}}$} & 1.171 & 1.416 & 1.278 & 1.779 \\
\hline & 8.000 & 8.000 & 8.000 & 8.000 \\
\hline $\mathrm{Al}^{\mathrm{VI}}$ & 2.783 & 3.153 & 3.266 & 3.839 \\
\hline $\mathrm{Ti}$ & - & - & 0.065 & 0.041 \\
\hline $\mathrm{Cr}$ & - & - & - & - \\
\hline $\mathrm{Fe}^{\mathrm{t}}$ & 0.752 & 0.517 & 0.393 & 0.092 \\
\hline $\mathrm{Mg}$ & 0.535 & 0.419 & 0.385 & - \\
\hline \multirow[t]{2}{*}{$\mathrm{Mn}$} & - & - & - & - \\
\hline & 4.070 & 4.089 & 4.109 & 3.972 \\
\hline $\mathrm{Ca}$ & 0.091 & - & - & - \\
\hline $\mathrm{Na}$ & 0.146 & 0.298 & - & 0.350 \\
\hline \multirow[t]{2}{*}{$\mathrm{K}$} & 1.910 & 1.776 & 1.650 & 1.547 \\
\hline & 2.117 & 2.074 & 1.650 & 1.897 \\
\hline $\mathrm{Mu}$ & 92.484 & 85.340 & 99.639 & 81.439 \\
\hline $\mathrm{Pg}$ & 7.101 & 14.368 & - & 18.450 \\
\hline $\mathrm{Ce}$ & 0.415 & 0.292 & 0.361 & 0.111 \\
\hline $\begin{array}{r}\mathrm{Si} / \\
\mathrm{Al}^{\mathrm{IV}}\end{array}$ & 5.832 & 4.650 & 5.260 & 3.497 \\
\hline
\end{tabular}
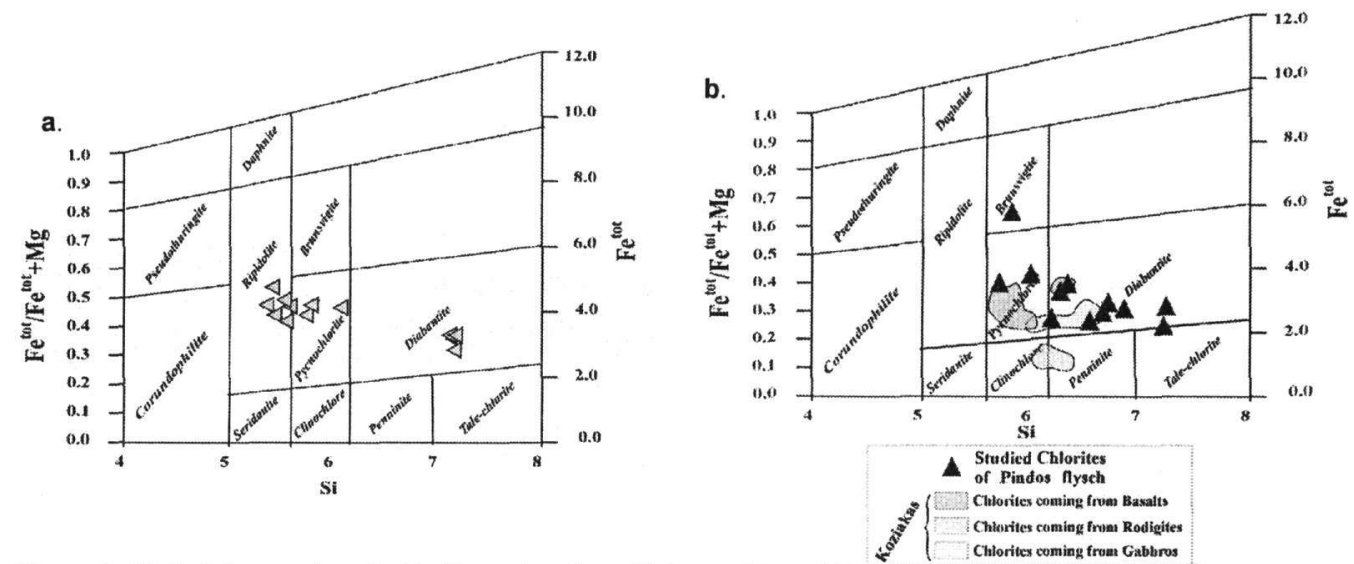

Figure 3. Plot of the analysed chlorite grains from Metsovo (a) and Fournas (b) on the classification diagram of Hey (1954); for comparison fields of chlorites from the ophiolitic complex of Koziakas are also shown (data from Pomonis, 2003). 
Table 4. Representative garnet microanalyses from Metsovo (Mets) and Fourna (F) areas. (-: below detection limit)

\begin{tabular}{|c|c|c|c|c|}
\hline & Mets10 & Mets10 & F12 & F16 \\
\hline & $k 5(1)$ & K5(2) & K2 (8') & $k 3\left(3^{\prime}\right)$ \\
\hline $\mathrm{SiO}_{2}$ & 37.25 & 39.08 & 39.07 & 39.15 \\
\hline $\mathrm{TiO}_{2}$ & - & - & - & \\
\hline $\mathrm{Al}_{2} \mathrm{O}_{3}$ & 20.19 & 23.51 & 22.92 & 20.61 \\
\hline $\mathrm{Cr}_{2} \mathrm{O}_{3}$ & - & - & - & \\
\hline $\mathrm{FeO}$ & 27.30 & 9.99 & 12.22 & 28.85 \\
\hline $\mathrm{MgO}$ & 1.53 & - & - & 4.51 \\
\hline $\mathrm{MnO}$ & 0.76 & - & - & 1.20 \\
\hline $\mathrm{CaO}$ & 8.63 & 22.42 & 22.82 & 3.68 \\
\hline $\mathrm{Na}_{2} \mathrm{O}$ & 0.62 & 0.38 & 0.33 & - \\
\hline Total & 96.28 & 95.38 & 97.36 & 98.00 \\
\hline \multicolumn{5}{|c|}{ Structural formulae on the basis of 120} \\
\hline $\mathrm{Si}$ & 3.065 & 3.130 & 3.083 & 3.156 \\
\hline \multirow[t]{2}{*}{$\mathrm{Al}^{\mathrm{IV}}$} & - & - & - & 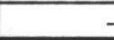 \\
\hline & 3.066 & 3.130 & 3.083 & 3.156 \\
\hline $\mathrm{Al}^{\mathrm{V}}$ & 1.956 & 2.218 & 2.130 & 1.957 \\
\hline $\mathrm{Ti}$ & - & - & - & - \\
\hline $\mathrm{Cr}$ & - & - & - & - \\
\hline \multirow[t]{2}{*}{$\mathrm{Fe}^{+3}$} & 0.044 & & - & - \\
\hline & 2.000 & 2.218 & 2.130 & 1.957 \\
\hline $\mathrm{Fe}^{+2}$ & 1.834 & 0.669 & 0.807 & 1.945 \\
\hline $\mathrm{Mg}$ & 0.188 & - & - & 0.542 \\
\hline $\mathrm{Mn}$ & 0.053 & - & - & 0.082 \\
\hline $\mathrm{Ca}$ & 0.761 & 1.924 & 1.930 & 0.318 \\
\hline \multirow[t]{2}{*}{$\mathrm{Na}$} & 0.099 & 0.059 & 0.050 & - \\
\hline & 2.935 & 2.652 & 2.787 & 2.887 \\
\hline Andr. & 2.200 & - & - & - \\
\hline Gros. & 24.634 & 74.200 & 70.515 & 11.015 \\
\hline Alm. & 64.669 & 25.800 & 29.485 & 67.371 \\
\hline Spes. & 1.869 & - & - & 2.840 \\
\hline Pyr. & 6.629 & - & - & 18.774 \\
\hline Uvar. & - & - & - & - \\
\hline
\end{tabular}

\subsection{Epidotes}

Representative epidote microanalyses are listed in Table 5 . $\mathrm{Fe}^{+2} / \mathrm{Fe}^{+3}$ ratios calculated according to stoichiometric considerations. The pistacite component ( $P S=100 \times \mathrm{Fe}^{+3}$ ) $\mathrm{Fe}^{+3}+\mathrm{Al}^{\mathrm{Vl}}$ ) in the epidotes from Metsovo ranges between 24.4 and 46.0 . The epidote grains from Fournas are clearly poorer in $\mathrm{Fe}^{\mathrm{t}}$ relative to the epidotes from Metsovo area, pointing to a different source and resulting in lower Ps contents (between 11.3 and 28.1). In both places, the pistacitic component in the analysed epidotes show no compositional gap, consistent with relatively HP/HT conditions during metamorphism, probably within amphibolite facies (e.g. Caruso et al. 1988, Freiberger et al. 2001). Significantly, the epidotes from Fournas, on a $\mathrm{Fe}^{\mathrm{t}} \mathrm{vs}$. $\mathrm{Al}^{\mathrm{V}}$ diagram, form a well defined trend, indicative for provenance from a unique source rock, and are strongly compared to epidotes from the Koziakas ophiolite (Fig. 4).

\subsection{Spinels}

Spinel microanalyses from Metsovo and Fournas areas are listed in Table 6 . In each area, there is one crystal is rich in $\mathrm{Cr}$ and one rich in Al. Cr-spinels are typically hosted in depleted rocks while $\mathrm{Al}$-spinels are commonly found in fertile Iherzolites. The low $\mathrm{Cr} \#(<60)$ spinels are analogous to those occurring in ultramafic rocks of oceanic (including backarc basin) origin (Dick \& Bullen, 1984). Chemical affinity of the detrital spinel grains from Metsovo and Fournas are similar and are compared well to those from Pindos ophiolite (Fig. 5).

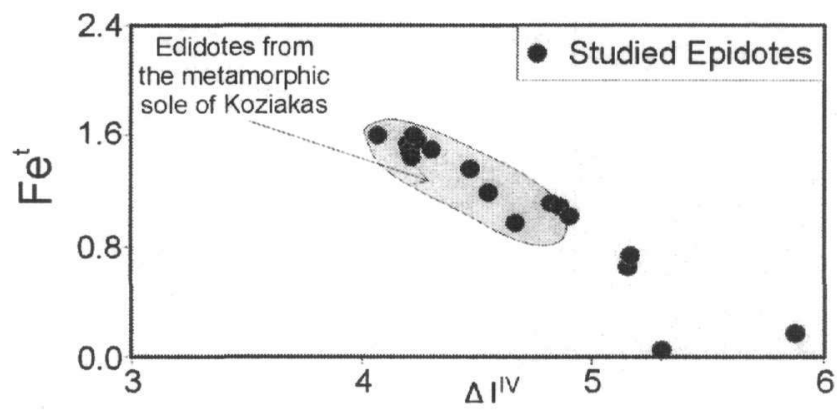

Figure 4. Projection of the compositions of the epidotes from Fournas on a Fe $\mathrm{e}^{\mathrm{t}} \mathrm{vs}$. All diagram. For comparison the field of the epidotes of the subophiolitic metamorphic sole of Koziakas are shown (data from Pomonis 2003). 
Table 5. Representative epidote microanalyses from Metsovo (Mets) and Fourna (F) areas. (-: below detection limit)

\begin{tabular}{|c|c|c|c|c|}
\hline & Mets6 & Mets10 & $\mathrm{F} 20$ & $\mathrm{~F} 20$ \\
\hline & $\mathrm{K} 2(\mathrm{~A})$ & $\mathrm{\kappa} 3(7)$ & K4(3) & K5(2) \\
\hline $\mathrm{SiO}_{2}$ & 38.60 & 40.14 & 38.62 & 39.57 \\
\hline $\mathrm{TiO}_{2}$ & - & - & - & - \\
\hline $\mathrm{Al}_{2} \mathrm{O}_{3}$ & 21.43 & 23.88 & 27.36 & 22.14 \\
\hline $\mathrm{Cr}_{2} \mathrm{O}_{3}$ & - & $-1-$ & - & - \\
\hline $\mathrm{Fe}_{2} \mathrm{O}_{3} \mathrm{t}$ & 15.62 & $\overline{12.71}$ & 9.18 & 13.55 \\
\hline $\mathrm{MgO}$ & - & - & - & - \\
\hline $\mathrm{MnO}$ & 0.70 & - & 0.46 & - \\
\hline $\mathrm{CaO}$ & 22.51 & 22.75 & 24.17 & 23.46 \\
\hline $\mathrm{Na}_{2} \mathrm{O}$ & 0.28 & - & - & 0.49 \\
\hline $\mathrm{K}_{2} \mathrm{O}$ & - & - & - & - \\
\hline Total & 99.14 & 99.48 & 99.79 & 99.21 \\
\hline \multicolumn{5}{|c|}{ Structural formulae on the basis of 250} \\
\hline $\mathrm{Si}$ & 6.119 & 6.224 & 5.950 & 6.214 \\
\hline \multirow[t]{2}{*}{$\mathrm{Al}^{\mathrm{N}}$} & - & - & 0.050 & - \\
\hline & 6.119 & 6.224 & 6.000 & 6.214 \\
\hline $\mathrm{Al}^{\mathrm{VI}}$ & 4.001 & 4.361 & 4.914 & 4.095 \\
\hline $\mathrm{Ti}$ & - & - & - & - \\
\hline \multirow[t]{2}{*}{$\mathrm{Fe}^{+3}$} & 1.860 & 1.48 & 1.063 & 1.600 \\
\hline & 5.861 & 5.841 & 5.977 & 5.695 \\
\hline $\mathrm{Fe}^{+2}$ & - & - & - & - \\
\hline $\mathrm{Mg}$ & - & - & - & - \\
\hline $\mathrm{Mn}$ & 0.094 & - & 0.060 & - \\
\hline $\mathrm{Ca}$ & 3.823 & 3,780 & 3.990 & 3.947 \\
\hline $\mathrm{Na}$ & 0.086 & - & - & 0.149 \\
\hline \multirow[t]{2}{*}{$\mathrm{K}$} & - & - & - & - \\
\hline & 4.003 & 3.780 & 4.050 & 4.096 \\
\hline Ps & 31.735 & 25.338 & 17.637 & 28.095 \\
\hline
\end{tabular}

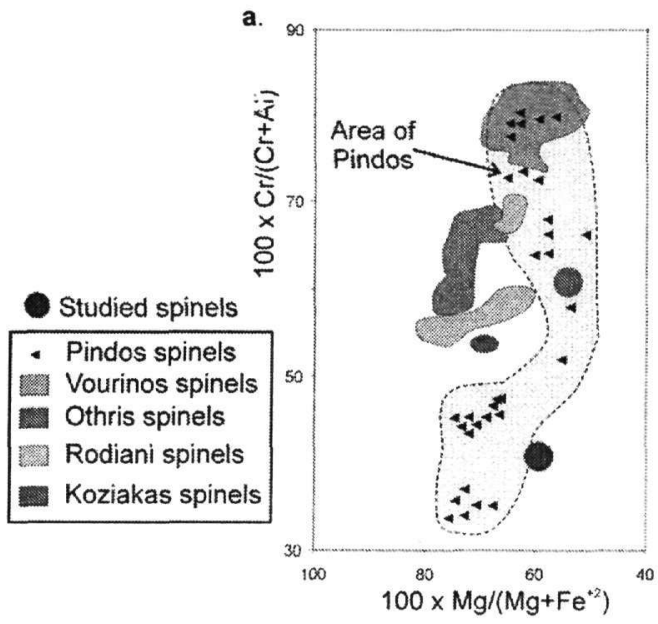

Table 6. Spinel microanalyses from Metsovo (Mets) and Fourna $(F)$ areas. (-: below detection limit)

\begin{tabular}{|c|c|c|c|c|}
\hline & Mets10 & Mets6 & F1 & $\mathrm{F} 12$ \\
\hline & $\mathrm{K} 6(3)$ & $\mathrm{K} 2(\mathrm{E})$ & $\mathrm{k} 2(1)$ & k2(13) \\
\hline $\mathrm{SiO}_{2}$ & 0.48 & 0.38 & 0.70 & 0.88 \\
\hline $\mathrm{TiO}_{2}$ & & & & \\
\hline $\mathrm{Al}_{2} \mathrm{O}_{3}$ & 20.38 & 32.90 & 22.50 & 31.53 \\
\hline $\mathrm{Cr}_{2} \mathrm{O}_{3}$ & 47.37 & 33.19 & 43.91 & 37.81 \\
\hline $\mathrm{FeO}^{1}$ & 18.73 & 17.45 & 18.52 & 14.01 \\
\hline $\mathrm{MnO}$ & - & 0.28 & & \\
\hline $\mathrm{MgO}$ & 11.57 & 13.58 & 12.96 & 14.99 \\
\hline $\mathrm{CaO}$ & 0.65 & 0.20 & 0.21 & \\
\hline $\mathrm{Na}_{2} \mathrm{O}$ & 0.43 & 0.56 & & \\
\hline $\mathrm{K}_{2} \mathrm{O}$ & 0.03 & & & \\
\hline Total & 99.64 & 98.54 & 98.80 & 99.22 \\
\hline \multicolumn{5}{|c|}{ Structural formulae on the basis of 320} \\
\hline $\mathrm{Si}$ & 0.121 & 0.091 & 0.175 & 0.206 \\
\hline $\mathrm{Al}$ & 6.037 & 9.244 & 6.610 & 8.711 \\
\hline $\mathrm{Cr}$ & 9.410 & 6.253 & 8.650 & 7.004 \\
\hline $\mathrm{Fe}^{+3}$ & 0.432 & 0.412 & 0.565 & 0.079 \\
\hline \multirow[t]{2}{*}{$\mathrm{Ti}$} & & & - & \\
\hline & 16.000 & 16.000 & 16.000 & 16.000 \\
\hline $\mathrm{Fe}^{+2}$ & 3.508 & 3.070 & 3.298 & 2.670 \\
\hline $\mathrm{Mn}$ & & 0.057 & & \\
\hline $\mathrm{Mg}$ & 4.339 & 4.83 & 4.819 & 5.242 \\
\hline $\mathrm{Ca}$ & 0.175 & 0.051 & 0.056 & \\
\hline $\mathrm{Na}$ & 0.210 & 0.259 & 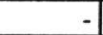 & \\
\hline $\mathrm{K}$ & 0.010 & & & \\
\hline
\end{tabular}

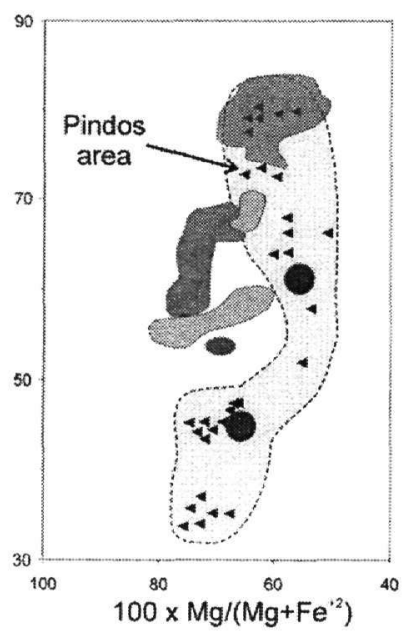

Figure 5. Composition of the analysed spinels from Metsovo (a) and Fournas (b) in comparison to spinels from Pindos, Othris, Vourinos, Koziakas and Rodiani ophiolites (data from Economou et al. 1986, 1995, 1999, Gartzos et al. 1990, Migiros et al. 1991 and Pomonis 2003). 


\section{SUPPLEMENTARY DATA}

\subsection{Paleocurrent data}

The main palaeocurrent directions of both Metsovo and Fourna areas interpreted from sole marks (flute and groove marks) indicate a south-southwest direction (Fig. 6), which means that the source of the material in both areas is from north-northeast. This fact is consistent with supply from the Pindos ophiolite and Pelagonian Zone for both areas, as well as from the Koziakas ophiolite for Fournas.
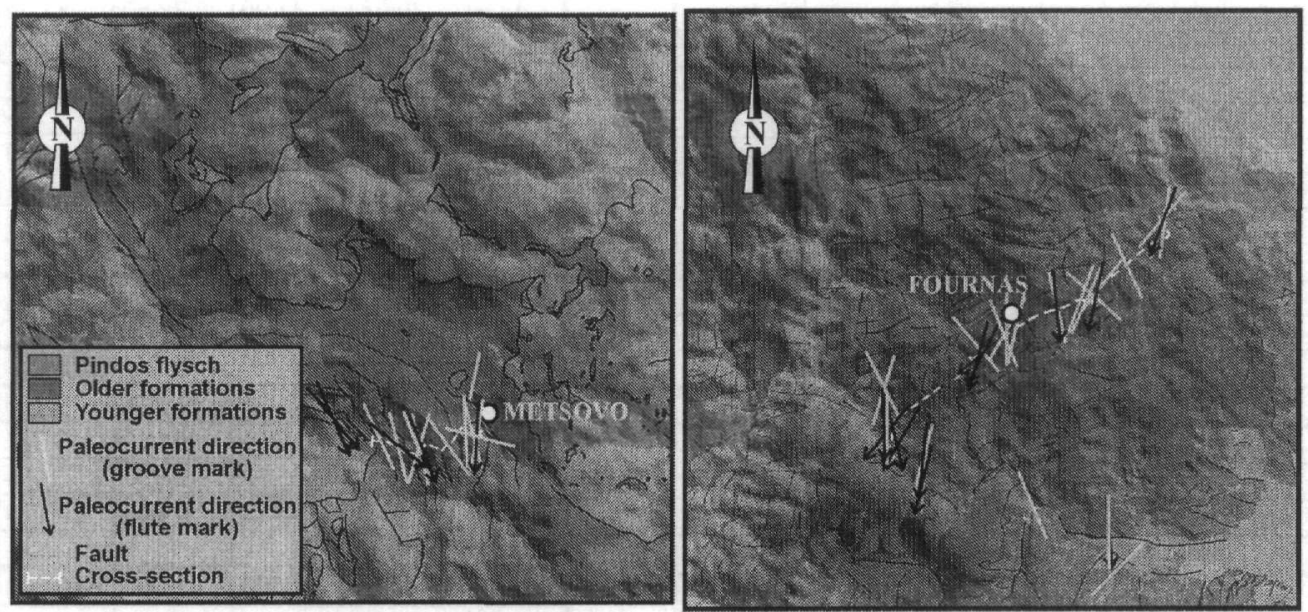

Figure 6. Simplified geological maps of the studied areas showing the main paleocurrent directions.

\section{CONCLUSIONS}

Microprobe analyses from Metsovo area combined with results from paleocurrent data reveal two different supply sources, the Pindos ophiolite and metamorphic rocks from the Pelagonian Zone. The Loumnitsa unit, in the Pindos ophiolite, may represent the source of the metamorphic materials, while spinels may have come from harzburgite of the Dramala complex. The source of acid materials may be the plutonite of Varnounta-Kastoria (Pelagonian mass). A unique tourmaline grain analysed arises a question about its provenance. The composition of the studied tourmaline is analogous to tourmalines from Polidendri-Kolchiko area of the Serbomacedonian massif, the latter comprises the most likely proximal source (Ananiadis 2003). However, absence of published analytical data from tourmalines from the Pelagonian Zone must be considered.

The same consideration for Fourna area (cross-section $I-I^{\prime}$ ) reveals Pindos and Koziakas ophiolites and Pelagonian mass as probable sources of the material. Thus, the studied spinels may have come from Pindos ophiolite, while the provenance of chlorites may be harzburgites, basalts and rodingites from the Koziakas ophiolite complex. The major part of the studied epidotes may have as a source Koziakas ophiolites, while the minor part may have come from amphibolite facies metamorphic rocks of the Pelagonian Zone.

\section{REFERENCES}

Ananiadis, G.E., 2003. Systematic analysis of submarine fans in the geotectonic zone of Pindos. Ph.D. Thesis, Univ. Patras, $395 \mathrm{pp}$.

Brown, E.H., 1977. The crossite content of Ca-amphibole as a guide to pressure of metamorphism. J. Petrol., $18,53-72$.

Caruso, L.J., Bird, D.K., Cho, M. and Liou, J.G., 1988. Epidote-bearing veins in the state 2-14 drill hole: Implications for hydrothermal fluid composition. J. Geoph. Res., 93, 123-133. 
Dick, H.J.B. and Bullen, 1984. Chromian spinel as a petrogenetic indicator in abyssal and Alpine-type peridotites and spatially as ;ociated lavas. Contrib. Mineral. Petrol., 86, 54-76.

Economou, M., Dimou, E., Economou, G., Migiros, G., Vacondios, I., Grivas, E., Rassios, A and Dabitzias, S.,1986. Chromite deposits of Greece. In: Cromites, IGCP 197 (Metallogeny of ophiolites), Athens, 129-159.

Economou-Eliopoulos, M. and Vakondios, I., 1995. Geochemistry of cromites and host rocks from the Pindos ophiolite complex, northwestern Greece. Chemical Geology, 122, 99-108.

Economou-Eliopoulos, M., Tarkian, M. and Sambanis, G., 1999. On the geochemistry of chromites from the Pindos ophiolite complex, Greece. Chemie der Erde, 59, 19-31.

Freiberger, R., Hecht, L., Cuney, M. and Morteani, G., 2001. Secondary Ca-Al silicates in plutonic rocks: implications for their cooling history. Contrib. Mineral. Petrol., 141, 415-429.

Gartzos, E., Migiros, G. and Parcharidis, I., 1990. Chromites from ultramafic rocks of northern Evia (Greece) and their geotectonic s. Jnificance. Schweiz. Miner. Petrograph. Mitt., 70, 301-307.

Guidotti, C.V. and Sassi, F.P., 1976. Muscovite as a petrogenetic indicator mineral in pelitic schists. N. Jb. Mineral. Abh., 127, 97-142.

Hey, M.H., 1954. A new review on the Chlorites. Min. Mag., 224, 277-298.

Massone, H.J. and Schreyer, W., 1986. High pressure syntheses and X-ray properties of white micas in the system $\mathrm{K}_{2} \mathrm{O}-\mathrm{MgO}-\mathrm{Al}_{2} \mathrm{O}_{5}-\mathrm{H}_{2} \mathrm{O}$. N. Jb. Miner. Abh., 153/2, 177-215.

Migiros, G.P., Stasinoulias, E., Stasinoulias, V. and Tsagalidis, A., 1991. The cromite occurrences in the ultrabasic rocks of Southern Pilio. Bull. Geol. Soc. Greece., 25, 2, 321-336.

Pomonis, P., 2003. The Koziakas ophiolite: Geological study, petrogenetic evolution, geotectonic interpretation. Ph.D. Thesis, Univ. Patras, 328pp.

Wilson, M. 1989. Igneous $\mathrm{r}$ atrogenesis. Unwin Hyman, London, $466 \mathrm{pp}$. 